\title{
O Câncer é Curável?
}

\author{
Is there a cure for cancer?
}

Mário Kroeff

Essa pergunta vem sendo feita, por toda parte, através de todos os tempos.

Certamente, não podemos comparar os processos de cura usados pela medicina de outrora, com os modernos recursos da ciência de hoje. Faz menos de um século que os doentes são operados no sono benéfico da anestesia, transportados ao reino da inconsciência, sem a necessidade de contenção pela força e sem os martírios do ferro em brasa ou da faca a sangue frio, usados por nossos antepassados.

São também da época de Pasteur os progressos da antisepsia e o uso do microscópio. Datam de alguns anos apenas, as descobertas de Roentgen e Madame Curie, que marcaram avanço decisivo no tratamento do Câncer e no progresso geral da medicina.

Nêste meio século, para orgulho da geração atual, a ciência médica tem melhorado inegavelmente os métodos de diagnóstico das doenças e aperfeiçoado imenso seus meios de cura. Em 35 anos de trabalho experimental sobre câncer em animais de laboratório, a humanidade aprendeu muito mais, do que em todos os séculos de empirismo, transcorridos para os nossos antepassados.

Hoje, confiantes nas possibilidades da medicina, os cancerólogos sustentam pelo mundo inteiro a afirmativa de que o câncer é curável, quando tratado no início. E nessa convicção, firmada no exemplo de outrem ou na própria experiência, os cancerologistas de hoje se empenham na luta, pondo em prática os recursos da moderna terapêutica, visando melhorar as percentagens de cura e superar os resultados, uns dos outros, numa verdadeira emulação profissional, onde se entrelaçam orgulho de homem e dever de humanidade. As estatísticas falam em favor desta afirmativa. O Colégio Americano de Cirurgiões mantém para estudo do câncer um registro de doentes curados, há mais de cinco anos. Até bem pouco com a documentação remetida pelos hospitais, já existiam 48.800 casos confirmados de cura persistente. Em breve, subirá o montante a 100.000, pois devemos lembrar que o registro data de alguns anos apenas. Cada um de nós possue também, ou tem notícia de casos que se conservaram curados por vários anos sem qualquer manifestação de recidiva. Mas a cura só se torna possível com o tratamento precoce, antes que a doença tenha tomado caráter de generalização, época em que passam a ser inúteis todos os recursos da medicina atual.

Os descrentes podem desfazer suas dúvidas, procurando os centros anti-cancerosos, onde terão ocasiāo de presenciar, como nós o comprovamos diàriamente no Serviço Nacional de Câncer: de um lado, o grande número de casos curados pela intervenção oportuna e adequada, a maioria das vezes articulando duas ou mais armas de combate; de outro, a multidão dos que caem na incurabilidade, por culpa própria, ou ainda, o que é mais comum, por tratamento mal conduzido ou mal iniciado.

$\mathrm{O}$ tratamento que visa a cura, baseia-se na suposição de ser o câncer, no início, doença local. A desordem celular que marca o ponto de partida da formação do tumor, dá-se em zona circunscrita do organismo, num grupo limitado de células. A histologia tem tido ocasião de surpreender esse fato nos córtes de lesões précancerosas, onde se esboça a cancerização e nos casos de câncer precocìssimamente diagnosticados.

A clínica também freqüentemente comprova que as manifestaçôes iniciais do câncer permanecem latentes, estacionárias por longo tempo, antes de manifestar-se de modo claro, dando oportunidade à intervenção terapêutica.

Mesmo que se admita, para explicar a gênese do câncer, a necessidade do fator irritação agindo em terreno predisposto à cancerização, ainda assim, a

Reprodução na íntegra da publicação original, mantendo-se a grafia da época Kroeff M. O câncer é curável? Rev Bras Cancerol 1947;1(1):77-8. 
modificação radioterápica do meio ou a remoção cirúrgica da porção afetada, quando a doença ainda estiver em sua fase local, pode transformar a situação mórbida e restabelecer as condiçôes normais.

Embora entre as causas orgânicas intrínsecas se aceite a origem endócrina ou metabólica do câncer, ainda assim, a destruição local das células doentes pode interromper o processo e evitar nova cancerização idêntica à primeira, se acaso cessar a crise hormonal por que passa o organismo periòdicamente, ou for compensado o desequilíbrio metabólico, espontaneamente, ou por terapêutica adequada.

O sucesso na cura do câncer depende essencialmente da intervenção oportuna, adequada e correta. Se, no início em cinco casos, curam-se quatro: no fim, talvez nem um sobre cinco.

Mas, não é só o diagnóstico precoce que condiciona a curabilidade do câncer. Se a intervenção não for conduzida dentro da boa técnica, obedecendo à verdadeira mentalidade anti-cancerosa, reduzem-se as possibilidades de cura e perde-se a ocasião apropriada.

Cada vez mais a cancerologia se firma como especialidade dentro da medicina e ela própria subdividida, quanto à terapêutica, em três ramos de adestramento especial, nunca de improvização momentânea.

Razão tiveram Ewing e Greenough em dizer:

"O diagnóstico e o tratamento do câncer já deixou de ser trabalho de um só homem - no longer one man job".

Enunciaram uma verdade. 